\title{
KONDISI OSEANOGRAFI FISIKA DAN KIMIA PERAIRAN DI TELUK MISKAM KAWASAN PESISIR TANJUNG LESUNG PADA BULAN APRIL 2013
}

\author{
PHYSICAL AND CHEMICAL OCEANOGRAPHY OF THE MISKAM BAY IN \\ THE TANJUNG LESUNG COASTAL WATERS DURING APRIL 2013
}

\author{
Mariska A. Kusumaningtyas ${ }^{1}$, Restu Nur Afi Ati ${ }^{1}$, Terry L. Kepel ${ }^{1}$, Agustin Rustam¹, \\ Hadiwijaya L. Salim ${ }^{1}$, \& Herlina Ika Ratnawati ${ }^{1}$ \\ ${ }^{1}$ Pusat Riset Kelautan, Badan Riset dan Sumber Daya Manusia KP, KKP \\ e-mail : astridkusuma@kkp.go.id \\ Diterima tanggal: 2 April 2018 ; diterima setelah perbaikan: 15 September 2020 ; Disetujui tanggal: 9 November 2020 \\ DOI: http://dx.doi.org/10.15578/jkn.v15i3.6607
}

\begin{abstract}
ABSTRAK
Pesisir Teluk Miskam memiliki potensi ekonomi terutama di sektor budidaya perikanan laut dan pariwisata, salah satunya di kawasan Tanjung Lesung, dimana melalui Peraturan Pemerintah Daerah Provinsi Banten No. 26 Tahun 2012, kawasan ini ditetapkan sebagai Kawasan Ekonomi Khusus Pariwisata. Pesatnya pembangunan di kawasan pesisir memberi dampak positif terhadap pertumbuhan perekonomian, namun di sisi lain dikhawatirkan dapat memberi dampak negatif terhadap kesehatan lingkungan perairan di sekitarnya, seperti di perairan Teluk Miskam. Guna mengetahui kondisi kualitas perairan Teluk Miskam, maka dilakukan pengukuran parameter fisika dan kimia perairan yang dilakukan pada April 2013 (musim peralihan I). Hasil penelitian ini diharapkan dapat bermanfaat untuk mendukung pengelolaan dan pemanfaatan sumberdaya pesisir yang berkelanjutan di kawasan pesisir Teluk Miskam. Pengambilan data dilakukan di 20 titik pengamatan di perairan Teluk Miskam. Parameter lingkungan yang dianalisa antara lain suhu, salinitas, $\mathrm{pH}$, oksigen terlarut dan konduktivitas, yang diukur menggunakan alat multiparameter secara in-situ. Sampel air juga dibawa ke laboratorium untuk diukur kandungan nutriennya (nitrat, nitrit, ammonia, ortofosfat dan silikat). Data hasil pengukuran kemudian dipetakan untuk mengetahui distribusi spasial-nya, lalu nilainya dibandingkan dengan baku mutu air laut untuk biota laut (Kepmen LH No. 51 Tahun 2004), dan dianalisa kriteria kualitas airnya berdasarkan indeks STORET. Hasil penelitian menunjukkan bahwa Perairan Teluk Miskam cenderung bersifat eutropik, dimana terjadi pengkayaan nitrat dan ortofosfat. Meski demikian, kondisi parameter suhu, $\mathrm{pH}$, DO dan silikat perairan Teluk Miskam masih tergolong baik dalam menunjang biota laut.
\end{abstract}

Kata Kunci: Kondisi oseanografi, fisika dan kimia perairan, Teluk Miskam, Tanjung Lesung, april 2013.

\section{ABSTRACT}

The coastal areas surrounding the Miskam Bay have economic potentials, particularly in marine aquaculture and tourism sectors, such as in the Tanjung Lesung region, which was declared as a Special Economic Zone for Tourism by the Government of Banten Province through the Regulation Number 26 Year 2012. The fast development in coastal area is expected to trigger an economic growth. However, there is a concern that the uncontrolled coastal activities can have negative impacts to the surrounding waters, such as in the Miskam Bay. In order to obtain an existing condition of the Miskam Bay, we measured the physical and chemical parameters of its water on April 2013 (during the transitional season I). Data collection was undertaken at 20 point stations. Temperature, salinity, $\mathrm{pH}$, dissolved oxygen and conductivity were measured in situ by using multiparameter instrument. Sea surface water was sampled for nutrient (nitrate, nitrite, ammonia, orthophosphate, and silicate) analysis in the laboratory. Data were mapped to obtain the spatial distribution, and the values were compared to the standard of sea water quality for biota based on the Ministry of Environmental No 51 year 2004, and the status of water quality was determined by using the STORET index. The results indicate that Miskam Bay tend to be eutrophic, with high nitrate and orthophosphate concentrations. However, the temperature, pH, DO, and silicate are generally still suitable to support marine life.

Keywords: Oceanographic condition, physical-chemical seawaters, Miskam Coastal Bay, Tanjung Lesung Beach, transitional season.

$\overline{\text { Kondisi Oseanografi Fisika dan Kimia Perairan di Teluk Miskam Kawasan Pesisir Tanjung Lesung Pada Bulan April } 2013}$ - Mariska A. Kusumaningtyas, Restu Nur Afi Ati, Terry L. Kepel, Agustin Rustam, 


\section{PENDAHULUAN}

Indonesia yang merupakan negara kepulauan dengan dua pertiga luas lautan lebih besar daripada daratan memiliki potensi sumberdaya laut dan pesisir yang besar meliputi hutan mangrove, terumbu karang, padang lamun, rumput laut, dan perikanan laut (Dahuri et al., 1996), sehingga memiliki nilai strategis secara ekonomi (Hakim, 2013). Pesatnya pembangunan perekonomian di kawasan pesisir dapat memberi manfaat positif bagi peningkatan kualitas hidup masyarakatnya, namun juga dikhawatirkan dapat memberikan dampak negatif terhadap lingkungan perairan jika tidak dikelola dengan baik. Polusi dan limbah yang berasal dari aktivitas antropogenik seperti limbah perikanan, pertanian, industri, perkapalan, wisata bahari, dan sebagainya dapat menyebabkan pencemaran lingkungan perairan, yang berpotensi menjadi racun bagi biota laut, atau memicu alga bloom (Islam \& Tanaka, 2004; Karydis, 2009). Strategi pembangunan pesisir perlu adanya penguatan di segala sektor, terutama peningkatan pelestarian ekologi secara menyeluruh untuk menjamin keberlangsungan sumberdaya alam (Hakim, 2013).

Salah satu kawasan yang memiliki sumberdaya pesisir dan laut dengan potensi ekonomi untuk dikembangkan yaitu kawasan Tanjung Lesung, Kabupaten Pandeglang, Provinsi Banten. Selain sektor perikanan, pengembangan ekonomi Tanjung Lesung juga difokuskan pada sektor pariwisata. Melalui PP. No. 26
Tahun 2012, Tanjung Lesung telah ditetapkan sebagai Kawasan Ekonomi Khusus (KEK) Pariwisata guna mendorong laju pertumbuhan ekonomi daerah tersebut (Dinas Kebudayaan dan Pariwisata Provinsi Banten, 2013). Teluk Miskam yang terletak di pesisir Tanjung Lesung menjadi salah satu lokasi yang terdampak langsung oleh aktivitas perekonomian di pesisir Tanjung Lesung. Perairan Teluk Miskam mempunyai potensi ekosistem pesisir utama yaitu lamun, terumbu karang dan mangrove (Rustam et al., 2015; Ati et al., 2015), yang memiliki peran dan fungsi ekologis penting bagi keberlanjutan sumberdaya hayati secara keseluruhan, sehingga perlu dijaga kondisinya. Padang lamun di daerah Tanjung Lesung dahulu diketahui merupakan habitat dugong yang pada 1992 pernah tertangkap nelayan setempat (Kiswara \& Tomascik, 1994). Selain itu Teluk Miskam merupakan daerah yang potensial untuk dikembangkan sebagai tempat budidaya kerang $M$. meretrix yang bernilai ekonomis karena topografi yang landai dan mendapat masukan nutrien dari sungai (Rudi, 2000).

Kualitas suatu perairan dapat diketahui dengan mengukur parameter biologi, fisika dan kimia perairan, dimana sebaran atau distribusinya sangat dipengaruhi oleh kondisi hidrodinamika perairan. Secara umum hidrodinamika Teluk Miskam dipengaruhi oleh pergerakan massa air dari Selat Sunda dan tiga sungai yaitu Sungai Ciliman, Sungai Cisekeut dan Sungai Cibungur (Kiswara \& Tomascik, 1994), yang polanya ditentukan oleh musim. Penelitian ini bertujuan

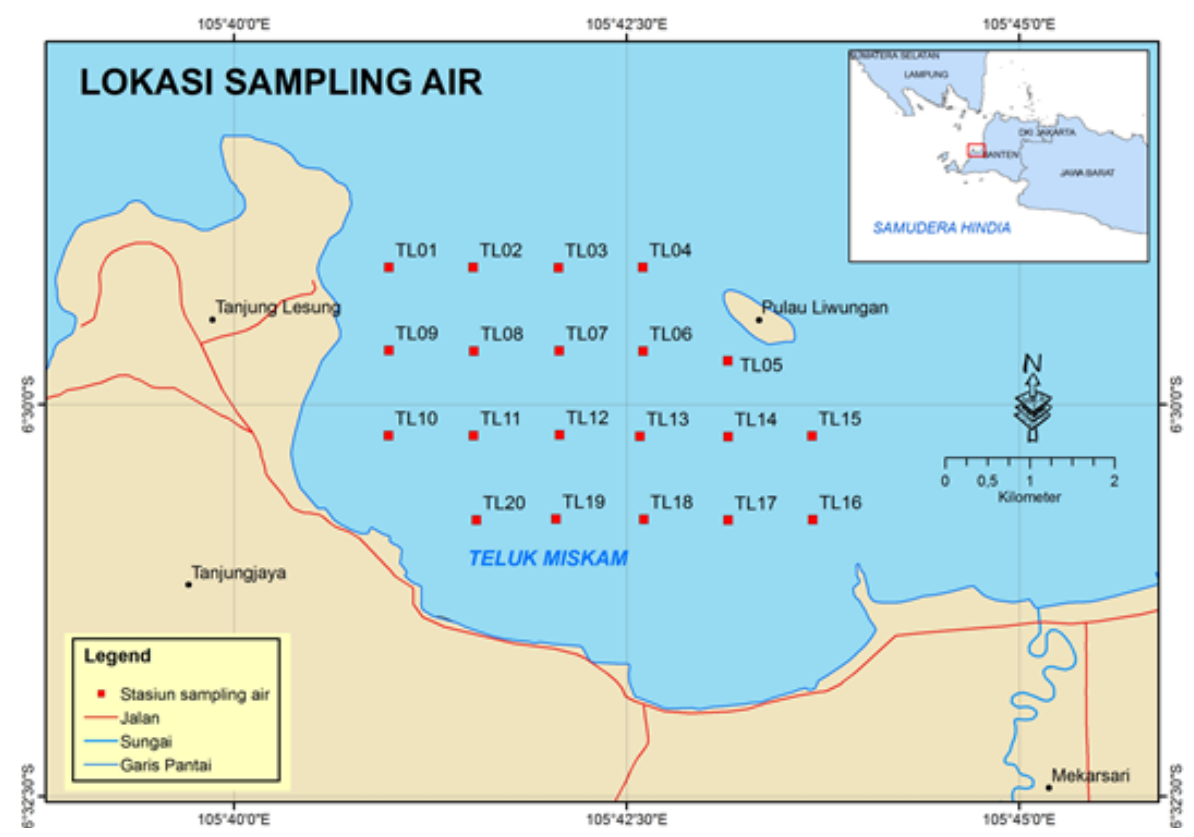

Gambar 1. Peta lokasi penelitian di Teluk Miskam.

Figure 1. Map of study site in Miskam Bay.

JURNAL KELAUTAN NASIONAL, Vol. 15, No 3, Desember 2020, Hal. 133-142 
mengukur kualitas air di Teluk Miskam berdasarkan parameter fisika dan kimia perairan, mengetahui sebaran atau distribusi parameter tersebut, dan mengidentifikasi keterkaitan antar parameter dalam mempengaruhi kondisi Perairan Teluk Miskam. Hasil penelitian ini diharapkan dapat memberi gambaran kondisi oseanografi di Perairan Teluk Miskam kawasan Pesisir Tanjung Lesung.

\section{BAHAN DAN METODE}

\section{Lokasi dan waktu penelitian}

Teluk Miskam terletak di sebelah Tenggara Selat Sunda, tepatnya masuk Kecamatan Panimbang, Kabupaten Pandeglang, Provinsi Banten. Kawasan pesisir di sekitar Teluk Miskam dimanfaatkan untuk pemukiman, tambak budidaya dan wisata. Pengukuran parameter kualitas perairan secara in situ serta pengambilan sampel air laut dilakukan pada 8-12 April 2013, di 20 titik stasiun pengukuran (Gambar 1).

\section{Pengambilan data}

Data parameter perairan yang diukur pada penelitian adalah parameter fisika dan kimia yang meliput suhu, salinitas, $\mathrm{pH}$, oksigen terlarut, konduktivitas dan nutrien (nitrat, nitrit, ammonia, ortofosfat dan silikat). Parameter suhu, salinitas, $\mathrm{pH}$, oksigen terlarut dan konduktivitas diukur secara insitu menggunakan alat multiparameter yang diturunkan pada kedalaman permukaan, sedangkan untuk analisa nutrien, diambil sampel air permukaan dan disimpan kedalam botol, yang selanjutnya dilakukan analisa di laboratorium.
Tabel 1. Kriteria kualitas air berdasarkan US-EPA Table 3. Seawater standart based on US-EPA

\begin{tabular}{llll}
\hline No & Kelas & Skor & Mutu air \\
\hline 1 & A & 0 & baik sekali \\
2 & B & $-1 \mathrm{~s} / \mathrm{d}-10$ & baik \\
3 & C & $-11 \mathrm{~s} / \mathrm{d}-30$ & tercemar sedang \\
4 & D & $\geq-31$ & buruk/tercemar \\
\hline
\end{tabular}

\section{Analisa Data}

Analisa data antara lain pembuatan profil sebaran atau distribusi spasial parameter fisika dan kimia perairan, analisa statistik korelasi dan keterkaitan antar parameter perairan menggunakan uji regresi linear, dan penentuan kualitas perairan dengan cara membandingkan nilai masing-masing parameter perairan dengan baku mutu air laut untuk biota laut yang dikeluarkan melalui KepMen Lingkungan Hidup No 51 tahun 2004 (lampiran III). Selanjutnya analisa kriteria kualitas/ mutu air dihitung menggunakan indeks STORET yang tercantum pada KepMen LH no 115 tahun 2003 yaitu menggabungkan hasil perhitungan parameter fisika dan kimia menggunakan sistem nilai khusus, kemudian membandingkan total skor tersebut dengan kriteria mutu air yang dikeluarkan oleh Kementrian Lingkungan Hidup yang diadopsi dari "US-EPA (Environmental Protection Agency)" yang dapat dilihat dalam Tabel 1. Pada penelitian ini, indeks STORET digunakan karena cukup sensitif untuk menentukan kriteria kualitas air (Barokah et al., 2017).

Tabel 2. Hasil pengukuran parameter fisika dan kimia perairan di Teluk Miskam pada bulan April 2013 Table 2. Chemical and physical parameters seawater quality values in Miskam Coastal Bay during April 2013

\begin{tabular}{|c|c|c|c|c|c|}
\hline Parameter & Baku Mutu & Rata-rata & $\pm S D$ & Kisaran & Koef.var (\%) \\
\hline \multicolumn{6}{|l|}{ Parameter fisika } \\
\hline Suhu $\left({ }^{\circ} \mathrm{C}\right)$ & $28-30$ & 29,93 & 0,43 & $29,10-30,80$ & 1 \\
\hline Konduktivitas $(\mathrm{mS} / \mathrm{m})$ & - & 3,12 & 0,59 & $1,72-3,73$ & 19 \\
\hline \multicolumn{6}{|l|}{ Parameter kimia } \\
\hline Salinitas (PSU) & $33-34$ & 20,02 & 4,07 & $10,37-24,33$ & 20 \\
\hline $\mathrm{pH}$ & $7-8.5$ & 8,20 & 0,07 & $7,97-8,30$ & 1 \\
\hline Oksigen Terlarut (mg/L) & $>5$ & 9,33 & 0,61 & $8,66-11,28$ & 7 \\
\hline Nitrat (mg/L) & 0.008 & 0,086 & 0,082 & $0,016-0,317$ & 95 \\
\hline Nitrit (mg/L) & $<0.06$ * & 0,008 & 0,004 & $0,004-0,020$ & 48 \\
\hline Ammonia (mg/L) & 0.3 & 0,123 & 0,151 & $0,040-0,655$ & 123 \\
\hline Ortofosfat (mg/L) & 0.015 & 0,049 & 0,095 & $0,010-0,394$ & 195 \\
\hline Silikat (mg/L) & $>0,14-0,28$ ** & 0,440 & 0,190 & $0,180-0,940$ & 43 \\
\hline
\end{tabular}

Keterangan: Baku mutu air untuk biota laut berdasarkan Kepmen LH no 51 tahun 2004

${ }^{*}$ ) Berdasarkan The Canadian Council of Resources and Environment Minister (dalam Effendi, 2003)

${ }^{* *}$ Tsunogai (1979) dalam Tsunogai \& Watanabe (1983)

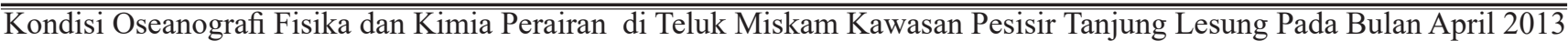



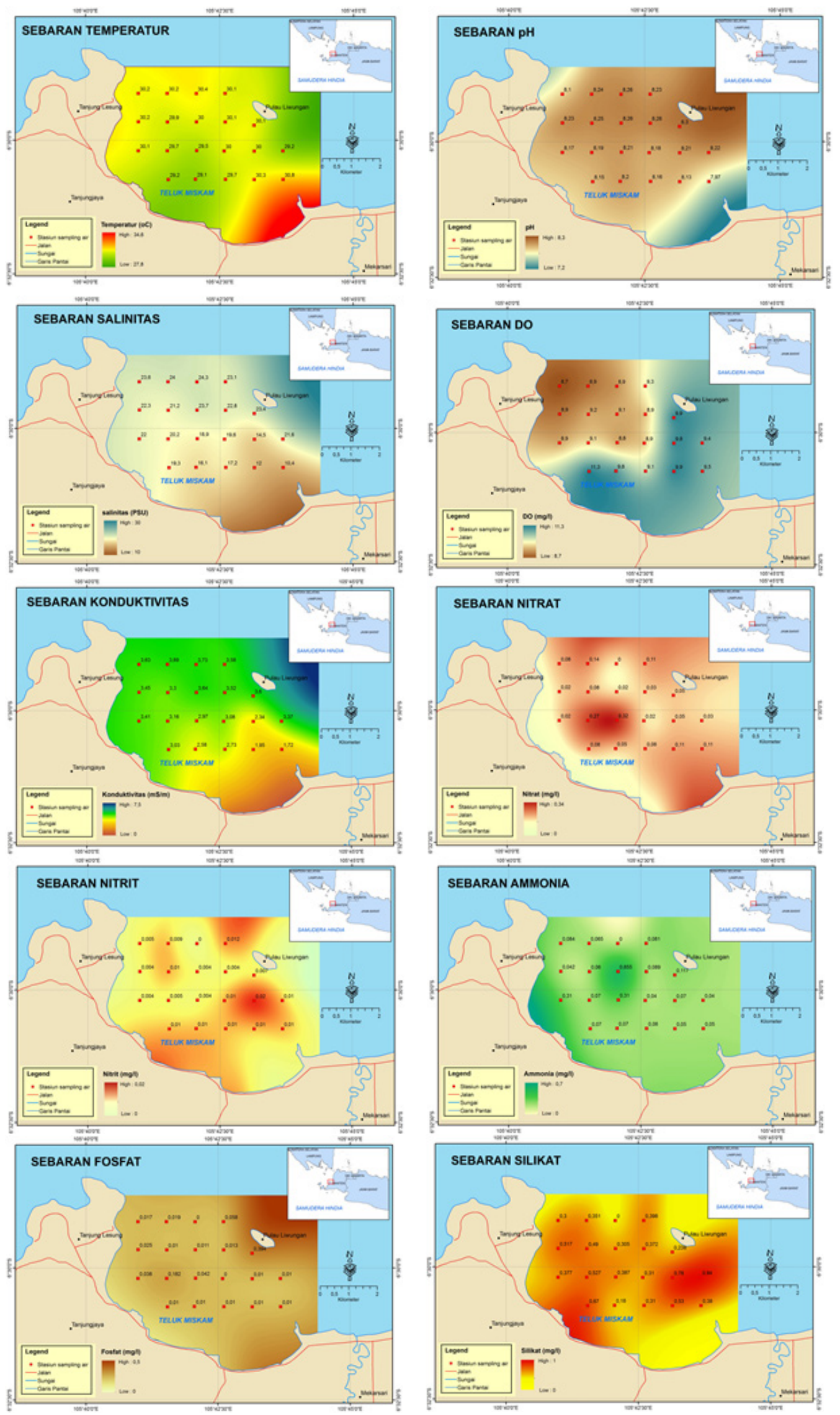

Gambar 2. Sebaran parameter fisik dan kimia perairan Teluk Miskam, April 2013.

Figure 2. Distribution profile of physical and chemical seawater quality in Miskam Coastal Bay, April 2013. 


\section{HASIL DAN PEMBAHASAN}

Nilai rata-rata dan kisaran masing-masing parameter kualitas perairan di Teluk Miskam pada bulan April 2013 serta baku mutu air laut untuk biota laut berdasarkan KepMen LH No 51 tahun 2004 dapat dilihat pada Tabel 2. Pada saat data tersebut diambil, parameter suhu, $\mathrm{pH}$, oksigen terlarut, ammonia dan silikat masih memenuhi baku mutu air laut KepMen LH no. 51 tahun 2004. Sedangkan parameter salinitas, nitrat, nitrit dan ortofosfat tidak memenuhi baku mutu air laut untuk biota laut. Perairan Teluk Miskam merupakan perairan estuari tempat tiga sungai bermuara, sehingga banyak mendapatkan masukan material dari darat yang mempengaruhi suhu harian, salinitas, $\mathrm{pH}$, oksigen terlarut (DO), konduktivitas dan kandungan nutrien perairan. Berdasarkan peta sebaran spasial (Gambar 2), secara umum semua parameter kualitas perairan Teluk Miskam cenderung bervariasi dari satu titik ke titik lain.

Kisaran suhu permukaan di perairan Teluk Miskam (29,10-30,80 $\left.{ }^{\circ} \mathrm{C}\right)$ pada saat penelitian masih tergolong baik dalam menunjang kehidupan biota laut (karang, lamun dan mangrove) berdasarkan baku mutu KepMenLH No. 51 tahun 2004. Selain itu, ikan pelagis kecil umumnya membutuhkan suhu antara $28-30{ }^{\circ} \mathrm{C}$ untuk hidup dan tumbuh (Rasyid, 2010). Kisaran suhu permukaan ini relatif lebih tinggi dibanding penelitian Rudi (2000) yang melaporkan suhu perairan Teluk Miskam berkisar antara 28-30 ${ }^{\circ} \mathrm{C}$. Perbedaan ini dapat terjadi akibat beberapa faktor seperti perbedaan intensitas penyinaran matahari saat pengambilan data, pengaruh dinamika arus pasang surut, angin atau aliran sungai (Hadikusumah, 2008), karena Teluk Miskam merupakan perairan estuari yang dinamis yang mendapatkan banyak masukan material dari darat sehingga mempengaruhi suhu harian. Pola sebaran suhu permukaan perairan Teluk Miskam cukup bervariasi (Gambar 2). Pada peta terlihat bahwa suhu tertinggi terpantau di bagian tenggara perairan (warna merah). Hal ini kemungkinan dipengaruhi oleh masuknya materi dari berbagai aktivitas ekonomi yang cukup intensif di pesisir bagian tenggara, seperti yang terpantau di lapangan, terutama aktivitas budidaya dan pertanian.

Salinitas permukaan di perairan Teluk Miskam pada saat penelitian berkisar antara 10,37-24,33 PSU, dengan pola sebaran cenderung meningkat dari pesisir ke arah laut lepas (Gambar 2). Nilai salinitas tersebut relatif lebih rendah dibanding nilai salinitas perairan estuaria di Indonesia pada umumnya, dengan variasi salinitas alami sebesar 15-32 PSU (Romimohtarto, 1985), juga lebih rendah dibanding baku mutu air laut yang menunjang pertumbuhan karang dan lamun. Rendahnya salinitas di perairan Teluk Miskam pada saat penelitian diduga karena menerima banyak input dari darat, sebab perairan Teluk Miskam merupakan muara dari DAS Ciliman, Cisekeut dan Cibungur. Berdasarkan data Dinas Sumberdaya Air dan Pemukiman (DSAP) Provinsi Banten, debit bulanan (April) pada sungai Ciliman sebesar $35,76 \mathrm{~m}^{3} / \mathrm{det}$; sungai Cisekeut yaitu $12,43 \mathrm{~m}^{3} / \mathrm{det}$; dan sungai Cibungur yaitu $29,89 \mathrm{~m}^{3} / \mathrm{det}$ (Ambarwati, 2015).

Nilai derajat keasaman $(\mathrm{pH})$ permukaan di perairan Teluk Miskam pada saat penelitan berkisar antara $7,97-8,30$, yang tergolong bersifat oseanik atau sama dengan $\mathrm{pH}$ di perairan laut lepas $(7-8,5)$. Nilai $\mathrm{pH}$ tersebut lebih tinggi dibanding penelitian sebelumnya yang terukur sebesar 6-7 (Rudi, 2000), namun masih memenuhi kriteria baku mutu berdasarkan KepMenLH (2004) yang baik dalam menunjang pertumbuhan karang, lamun, mangrove, juga dalam menunjang usaha budidaya perikanan laut. Sebaran spasial $\mathrm{pH}$ cenderung homogen meski salah satu stasiun di sisi tenggara menunjukkan nilai $\mathrm{pH}$ yang lebih rendah (Gambar 2), yang diduga dipengaruhi oleh masukan dari berbagai aktivitas di darat yang cukup intensif di bagian tenggara.

Nilai konduktivitas permukaan di perairan Teluk Miskam berkisar antara 1,72-3,73 mS/m. Konduktivitas adalah kemampuan larutan menghantarkan arus listrik. Kemampuan tersebut tergantung keberadaan dan mobilitas ion, sehingga semakin banyak kandungan garam yang terlarut, semakin tinggi pula nilai konduktivitas (Effendi, 2003), seperti yang terlihat pada korelasi yang erat antara konduktivitas dan salinitas dengan nilai $\mathrm{p}<0.001$.

Kandungan oksigen terlarut(DO) permukaan di perairan Teluk Miskam pada saat penelitian berkisar antara 8,66 - 11,28 mg/L. Nilai DO tersebut terpantau lebih tinggi dibanding penelitian sebelumnya yaitu berkisar antara $4,76-5,95 \mathrm{mg} / \mathrm{L}$ (Rudi, 2000). Kandungan oksigen terlarut di permukaan perairan umumnya berasal dari difusi langsung dari udara, aerasi, atau sebagai produk hasil fotosintesis (Salmin, 2005). Kelarutan oksigen di dalam air juga dapat dipengaruhi oleh suhu dan salinitas. Kadar oksigen terlarut dalam air laut akan berkurang dengan semakin tingginya suhu dan salinitas (Odum, 1971), namun pada penelitian ini tidak terdapat korelasi yang erat antara kadar DO dengan suhu $\left(p\right.$-value $\left.=0,103 ; r^{2}=0,093\right)$ maupun antara DO 
dengan salinitas $\left(\mathrm{p}=0,083 ; \mathrm{r}^{2}=0,110\right.$; Gambar 3 dan 4), sehingga lebih tingginya kandungan DO pada saat penelitian ini kemungkinan dipengaruhi oleh tingginya aktivitas fotosintesis misalnya dari fitoplankton, yang ditandai oleh tingginya nitrat dan fosfat (Tabel 2) yang merupakan nutrien yang dibutuhkan fitoplankton untuk melakukan fotosintesis. Kadar DO yang terlalu tinggi atau terlalu rendah memang dapat membahayakan biota laut, namun demikian, nilai DO di perairan Teluk Miskam masih memenuhi baku mutu untuk biota laut $(>5 \mathrm{mg} / \mathrm{L})$, sehingga masih tergolong baik dalam menunjang usaha budidaya perikanan laut. Peta sebaran spasial DO menunjukkan warna yang kontras antara bagian barat dan tenggara, dimana sebaran DO terpantau lebih tinggi di tenggara (Gambar 2).

Nitrat, nitrit dan ammonia merupakan bentuk utama dari nitrogen dan merupakan nutrien penting yang

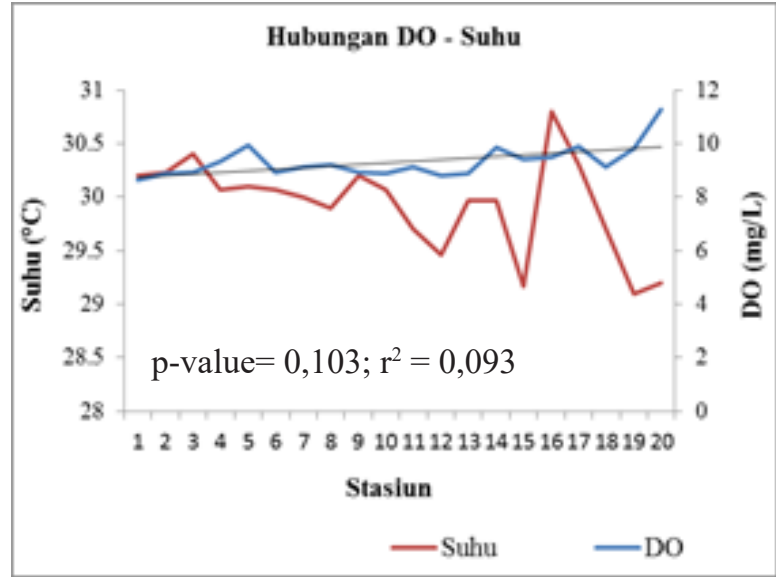

Gambar 3. Korelasi antara DO dan suhu. Figure 3. Correlation between DO with temperature.

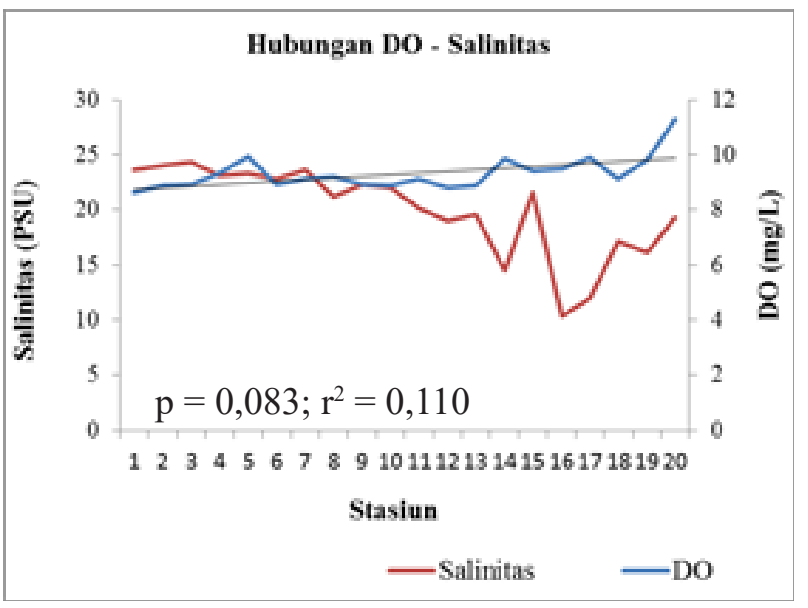

Gambar 4. Korelasi antara DO dan salinitas. Figure 4. Correlation between DO and salinity. keberadaannya dibutuhkan oleh tumbuhan hijau untuk proses fotosintesis (Mackentum, 1969). Namun demikian, keberadaan nutrien yang berlebih dalam suatu perairan dapat berpengaruh buruk antara lain memicu ledakan pertumbuhan alga, yang dapat menurunkan kualitas perairan dan menyebabkan kematian massal ikan. Hasil pengukuran nitrat di perairan Teluk Miskam pada saat penelitian menunjukkan kisaran antara 0,016 - 0,317 mg/L, dengan rata-rata 0,086 $\mathrm{mg} / \mathrm{L}$. Kisaran nitrat yang terukur pada penelitian ini melebihi baku mutu yang dikeluarkan melalui KepMenLH 2004 yaitu 0,008 mg/L (Gambar 5). Hal tersebut mengindikasikan bahwa perairan Teluk Miskam pada saat pengukuran mengalami pengkayaan nitrat. Kandungan nitrat umumnya tidak berbahaya bagi perikanan jika dibanding ammonia dan nitrit, namun jika kandungannya sangat tinggi dapat menjadi racun bagi hewan budidaya seperti udang (Kuhn et al., 2011). Tingginya kandungan nitrat di perairan dapat disebabkan oleh beberapa faktor, antara lain tingginya kandungan oksigen terlarut (DO) yang memicu bakteri mengoksidasi ammonia menjadi nitrat (Herbert, 1999), nilai $\mathrm{pH}$ perairan yang cenderung basa sehingga meningkatkan kandungan nitrat, atau dapat juga terjadi akibat akumulasi limbah budidaya perikanan (Qian et al., 2001; WHO \& European Commission, 2002; Hetty et al., 2005).

Hasil pengukuran kandungan nitrit di perairan Teluk Miskam menunjukkan kisaran antara 0,004 - 0,020 $\mathrm{mg} / \mathrm{L}$, dengan nilai rata-rata $0,008 \mathrm{mg} / \mathrm{L}$. Nilai tersebut lebih tinggi daripada kandungan nitrit pada perairan alami berdasarkan kriteria The Canadian Council of Resources and Environment Minister (dalam Effendi, 2003) yaitu sekitar $0,001 \mathrm{mg} / \mathrm{L}$. Meskipun demikian, kandungan nitrit di Teluk Miskam masih tergolong baik karena tidak melebihi $0,06 \mathrm{mg} / \mathrm{L}$ yang dapat

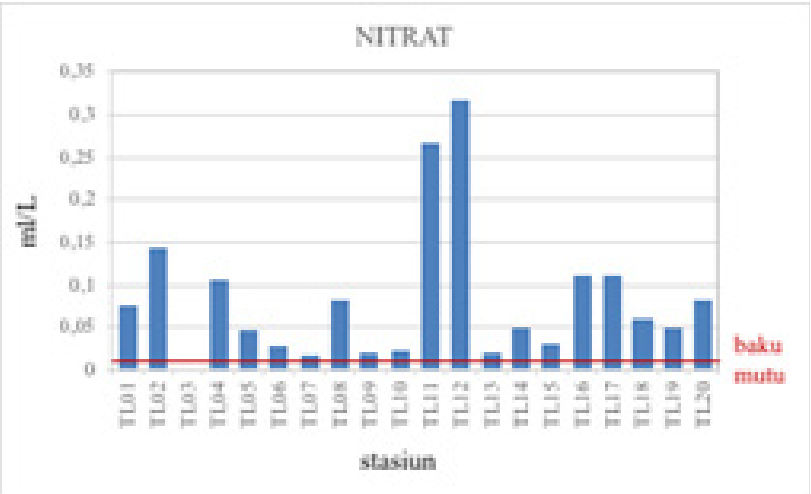

Gambar 5. Konsentrasi nitratterhadap baku mutu.

Figure 5. Nitrate concentration versus water quality standart. 
bersifat toksik. Pada perairan alami, nitrit biasanya ditemukan dalam jumlah yang sangat sedikit karena mudah teroksidasi dengan adanya oksigen. Dengan bantuan bakteri, oksigen terlarut akan mengoksidasi nitrit menjadi nitrat, sehingga konsentrasi nitrit di lapisan permukaan menjadi kecil (WHO \& European Commission, 2002).

Kandungan ammonia di perairan Teluk Miskam berkisar antara $0,040-0,655 \mathrm{mg} / \mathrm{L}$, dengan nilai rata-rata 0,123 $\mathrm{mg} / \mathrm{L}$. Nilai rata-rata tersebut masih memenuhi kriteria yang ditetapkan Kepmen LH yaitu di bawah $0,3 \mathrm{mg} / \mathrm{L}$ (Gambar 6). Meskipun demikian, kandungan ammonia pada stasiun 7, 10 dan 12 terpantau tinggi dan berada diambang batas baku mutu. Umumnya, sumber ammonia dapat berasal dari limpasan sungai atau dari limbah budidaya perikanan yang merupakan sumber utama ammonia (Damar, 2004, Qian et al., 2001). Hal ini perlu diperhatikan karena biota laut terutama ikan tidak dapat mentoleransi kadar ammonia bebas yang terlalu tinggi karena dapat mengganggu proses pengikatan oksigen oleh darah dan menyebabkan kematian (Effendi, 2003).

Hasil pengukuran kandungan ortofosfat di perairan Teluk Miskam menunjukkan kisaran antara 0,095 $0,394 \mathrm{mg} / \mathrm{L}$, dengan nilai rata-rata $0,49 \mathrm{mg} / \mathrm{L}$. Nilai tersebut lebih tinggi dari hasil pengukuran sebelumnya pada tahun 1993 di lokasi yang sama (Muchtar, 2000), yaitu sebesar $0,12-1,54 \mu \mathrm{g} / \mathrm{L}$ (sekitar 0,00012 $-0,00154 \mathrm{mg} / \mathrm{L}$ ). Pada beberapa stasiun (stasiun 2, 4, 5, 9, 10, 11 dan 12) bahkan menunjukkan kandungan ortofosfat yang melebihi baku mutu Kepmen LH yaitu di atas $0,015 \mathrm{mg} / \mathrm{L}$ (Gambar 7). Tingginya kandungan fosfat di perairan umumnya merupakan dampak langsung dari aktivitas antropogenik, seperti budidaya, pertanian, maupun pariwisata, seperti yang terpantau

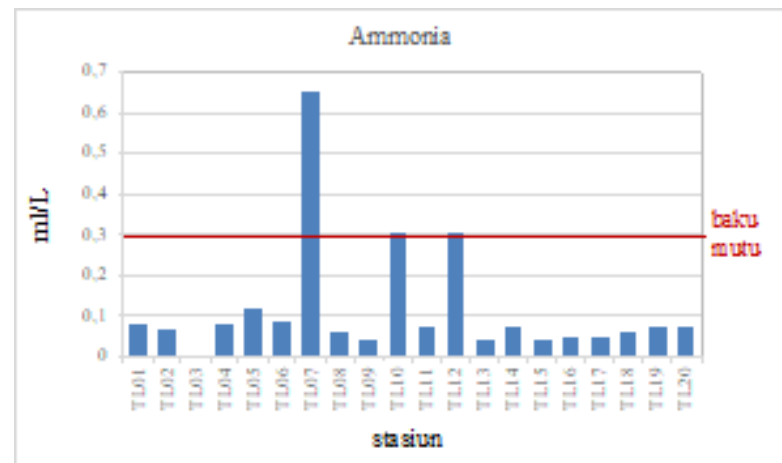

Gambar 6. Konsentrasi ammonia di semua stasiun terhadap baku mutu.

Figure 6. Ammonia concentration at all stations versus water quality standart.

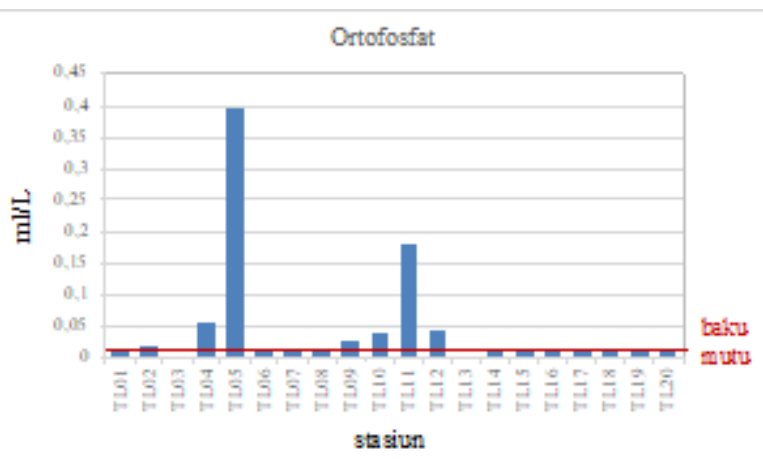

Gambar 7. Konsentrasi ortofosfat di semua stasiun terhadap baku mutu.

Figure 7. Ortophosphate concentration at all stations versus water quality standart.

di lokasi penelitian. Konsentrasi fosfat di perairan pesisir umumnya memang lebih tinggi dibanding pada perairan laut lepas karena pengaruh limpasan dari darat dan upwelling di pesisir (Chen \& Tsunogai, 1998). Fosfat merupakan salah satu senyawa nutrien yang sangat penting di laut karena berperan sebagai faktor pembatas pertumbuhan fitoplankton. Berdasarkan WHO \& European Commission (2002), kadar minimum fosfat untuk mendukung pertumbuhan plankton adalah sebesar $0,01 \mathrm{mg} / \mathrm{L}$, sedangkan konsentrasi sebesar 0,03 $-0,1 \mathrm{mg} / \mathrm{L}$ atau lebih dapat memicu terjadinya ledakan populasi plankton (alga bloom).

Kandungan silikat permukaan di perairan Teluk Miskam pada saat penelitian berkisar antara 0,180 - 0,940 mg/L, dengan nilai rata-rata $0,440 \mathrm{mg} / \mathrm{L}$. Silikat berperan untuk menunjang pertumbuhan dan perkembangan struktur ekstraselular diatom, sehingga silikat merupakan faktor pembatas pertumbuhan diatom (Koike et al., 2001). Diatom berperan dalam menghambat pertumbuhan fitoplankton lain yang mungkin berbahaya misalnya dinoflagelata (Tsunogai \& Watanabe, 1983). Umumnya, eutrofikasi yang diikuti dengan menurunnya ketersediaan silikat dapat memicu terbentuknya harmful alga bloom (Natural Research Council, 2000). Tsunogai (1979) dalam Tsunogai \& Watanabe (1983), menyatakan bahwa baku mutu silikat terlarut yang menunjang pertumbuhan dan perkembangan diatom yaitu $>5-10 \mu \mathrm{g}$-at $/ \mathrm{L}(>0,14-0,28$ $\mathrm{mg} / \mathrm{L}$ ), sehingga kisaran silikat pada perairan Teluk Miskam masih berada di atas kisaran minimum yang menunjang pertumbuhan diatom. Meskipun kandungan nitrat dan fosfat terpantau cukup tinggi dan berpotensi memicu harmful alga bloom, namun pertumbuhannya dapat dihambat oleh diatom.

$\overline{\text { Kondisi Oseanografi Fisika dan Kimia Perairan di Teluk Miskam Kawasan Pesisir Tanjung Lesung Pada Bulan April } 2013}$ 
Berdasarkan hasil perhitungan menggunakan indeks STORET, nilai kualitas air di Teluk Miskam yaitu terhitung sebesar -30 (kelas C) yang termasuk kategori tercemar sedang. Hal ini dimungkinkan karena beberapa nilai parameter yang di atas ambang baku mutu, seperti nitrat, ammonia dan ortofosfat. Hal ini dapat berdampak buruk pada kehidupan organisme laut di dalam perairan tersebut, dan juga pada perikanan budidaya, karena usaha budidaya memerlukan kualitas air laut yang optimal (Mustofa, 2015).

Nitrogen dan fosfat merupakan dua nutrien utama penentu kondisi tropik perairan. Nitrogen umumnya menjadi faktor nutrien pembatas eutrofikasi di pesisir, sedangkan fosfat merupakan faktor nutrien pembatas eutrofikasi di perairan tawar seperti danau (National Research Council, 2000; Howarth \& Marino, 2006). Dengan tingginya kandungan nitrat (di semua stasiun), ortofosfat (di stasiun 2, 4, 5, 9, 10, 11 dan 12), dan ammonia (di stasiun 7, 10 dan 12) yang melebihi baku mutu, perairan Teluk Miskam pada saat penelitian tergolong ke dalam perairan eutrofik atau kaya akan kandungan nutrien (Richardson et al., 2007). Perairan estuaria umumnya memang cenderung bersifat eutrofik karena menerima masukan nutrien secara langsung dari darat. Kawasan daratan di sekitar Teluk Miskam terpantau mengalami alih fungsi. Keberadaan ekosistem mangrove alami di sepanjang pesisir sudah sangat sedikit, dimana lahan mangrove banyak digunakan untuk perkembangan ekonomi terutama pariwisata (Ati et al., 2014) dan juga tambak. Limbah dari aktivitas antropogenik seperti industri, pertanian, dan budidaya perikanan merupakan sumber utama nitrogen dan fosfor yang masuk ke perairan (Conley et al., 2009).

Tingginya kandungan nutrien di suatu perairan dapat memicu terjadinya ledakan populasi alga (alga bloom). Namun pertumbuhan alga atau plankton sangat dipengaruhi oleh rasio $\mathrm{N}$ dan $\mathrm{P}$ yang terkandung dalam perairan. Sel fitoplankton memiliki ratio ratarata N/P sekitar 16:1 (Redfield, 1958), dan umumnya rasio $\mathrm{N} / \mathrm{P}$ di perairan yang menunjang pertumbuhan fitoplankton memiliki nilai yang serupa. Nutrien yang berpotensi sebagai faktor pembatas produksi primer dapat diprediksi berdasarkan rasio nutrien tersebut di dalam kolom air. Kompetisi fitoplankton akan nutrien pembatas tersebut menjadi faktor penting dalam menentukan komposisi komunitas plankton (Tilman et al, 1982), dan menjadi indikator terjadinya alga bloom. Nilai rata-rata rasio nitrogen dan fosfat (N/P) di perairan Teluk Miskam yaitu sekitar 4:1. Nilai rasio N/P tersebut relatif rendah, karena menurut Nontji (1984) dan Howarth \& Marino (2006), rasio N/P di perairan terbuka biasanya hampir konstan yaitu sekitar 15:1, atau hampir sama dengan rasio sel fitoplankton. Selain dipengaruhi oleh ketersediaan nutrien di kolom air, kompetisi fitoplankton akan nutrien juga dipengaruhi oleh perubahan parameter lingkungan yang kontinyu, antara lain seperti suhu, intensitas cahaya, salinitas, $\mathrm{pH}$ dan DO (Tilman et al., 1986; Khan \& Ansari, 2005). Eutrofikasi dapat memicu terjadinya ledakan plankton atau alga bloom jika sirkulasi air atau dinamika perairannya terbatas (Herbert, 1999).

\section{KESIMPULAN DAN SARAN}

Pada saat penelitian, terpantau adanya pengkayaan nutrien di perairan Teluk Miskam yang disebabkan tingginya kandungan nitrat, ammonia dan ortofosfat permukaan di beberapa titik sampling yang melebihi baku mutu yang ditetapkan KepMenLH No. 51 Tahun 2004, dimana berdasarkan indeks STORET, kriteria kualitas air di Teluk Miskam tergolong tercemar sedang. Perairan Teluk Miskam memiliki sumberdaya pesisir dan laut dengan potensi ekonomi untuk dikembangkan, sehingga perlu adanya manajemen lingkungan yang baik agar tidak terjadi kerusakan lingkungan yang berkelanjutan.

\section{UCAPAN TERIMA KASIH}

Ucapan terima kasih disampaikan kepada semua anggota tim Blue Carbon Pusat Riset Kelautan serta pihak-pihak yang terlibat dalam kegiatan survei dan analisa sampel. Pengukuran dan pengambilan sampel ini merupakan bagian dari kegiatan penelitian "Analisa Potensi Blue Carbon Di Wilayah Perairan Kepulauan Derawan dan Tanjung Lesung Sebagai Mitigasi Perubahan Iklim Global" Tahun Anggaran 2013 pada Puslitbang Sumberdaya Laut dan Pesisir - Badan Litbang Kelautan dan Perikanan, Kementerian Kelautan dan Perikanan. Analisis lanjutan menggunakan DIPA APBN TA 2020 unuk Pusriskel

\section{DAFTAR PUSTAKA}

Ati, R. N. A., Rustam, A., Kepel, T. L., Sudirman, N., Daulat, A., Mangindaan, P., Salim, H. L., Hutahaean, A., Kusumaningtyas, M. A. (2015). Stok karbon dan struktur komunitas mangrove sebagai Blue Carbon di Tanjung Lesung, Banten. Jurnal Segara, 10(2), 119-127.

Barokah, G. R., Ariyani, F. \& Siregar, T. H. (2017). 
Comparison of Storet and Pollution Index Method to assess the environmental status: A case study of Lampung Bay, Indonesia. Squalen Bull. of Mar. and Fish. Postharvest and Biotech., 12(2), 67-74.

Chen, C-T. A. \& Tsunogai, S. (1998). Carbon and nutrients in the ocean. In Galloway, J. N. \& Melillo, J. M. (Eds.) Asian Change in the Contex of Global Climate Change (pp.271-307). Cambridge Univ. Press.

Conley, D. J., Paerl, H. W, Howarth, R. W., Boesch, D. F. Seitzinger, S. P, Havens, K. E., Lancelot, C., \& Likens, G. E. (2009). Controlling Eutrophication: Nitrogen and Phosphorus. Science, 323, 10141015 .

Dahuri, R., Rais, J., Ginting, S. P., \& Sitepu, M. J. (1996). Pengelolaan Sumberdaya Pesisir dan Lautan Secara Terpadu. Jakarta: PT. Pramadya Paramita.

Damar, A. (2004). Effects of enrichment on nutrient dynamics, phytoplankton dynamics and productivity in Indonesian tropical waters: A comparison between Jakarta Bay, Lampung Bay and Semangka Bay. Disertasi. Der Mathematisch-Naturwissenschaftlichen Fakultät: der Christian-Albrechts-Universität.

Dinas Kebudayaan dan pariwisata Provinsi Banten. (2013). Analisis dampak sosial-ekonomi Kawasan Ekonomi Khusus Pariwisata Tanjung Lesung. Laporan Akhir I, Dinas Kebudayaan dan Pariwisata. Provinsi Banten: $141 \mathrm{hlm}$.

Effendi, H. (2003). Telaah kualitas air: Bagi pengelolaan sumber daya dan lingkungan perairan. Yogyakarta: Penerbit Kanisius.

Hadikusumah. (2008). Variabilitas suhu dan salinitas di Perairan Cisadane. Makara Sains, 12(2), 8288.

Hakim, M.F., (2013). Blue Economy daerah pesisir berbasis kelautan dan perikanan. Economics Development Analysis Journal, 2(2), 1-7.

Herbert, R. A. (1999). Nitrogen cycling in coastal water ecosystems. FEMS Microbiology Reviews, 23, 563-590.
Hetty, J. P., Hartono, D., Praptana, R. \& Setiadi, T. (2005). Biodegradasi Urea dalam Reaktor Sharon ${ }^{\circledR}$ : Pengaruh waktu tinggal cairan dan pH. Prosiding seminar nasional rekayasa kimia dan proses, Bandung, Indonesia.

Howarth, R. W. \& Marino, R. (2006). Nitrogen as the limiting nutrient for eutrophication in coastal marine ecosystems: Evolving views over three decades. Limnol. Oceanogr, 51, 364-376.

Islam, M. D. \& Tanaka, M. (2004). Impact of pollution on coastal and marine ecosystems including coastal and marine fisheries and approach for management: a review and synthesis. Mar. Pollut. Bull, 48, 624-649.

Karydis, M. (2009). Eutrophication assessment of coastal waters based on indicators: A literature review. Global NEST Journal, 11(4), 373-390.

Kementerian Lingkungan Hidup Republik Indonesia (KLH). (2003). Penentuan Status Mutu Air dengan Metoda Storet. Dalam: Keputusan Menteri Negara Lingkungan Hidup No.115 Tahun 2003 Tentang Pedoman Penentuan Status Mutu Air. KLH, Jakarta.

Kementerian Lingkungan Hidup Republik Indonesia (KLH). (2004). Baku mutu air laut untuk biota laut, Dalam: Keputusan Menteri Negara Lingkungan Hidup No.51 Tahun 2004 Tentang Baku Mutu Air Laut. KLH, Jakarta.

Khan, F. A \& Ansari, A. A. (2005). Eutrophication: An ecological vision. The Botanical Review, 71(4), 449-482.

Kiswara, W. \& Tomascik, T. (1994). The distribution of seagrasses in a dugong (Dugong dugong Müller) habitat in Miskam Bay, Sunda Strait, Indonesia. In Sudara, S., Wilkinson, C.R. \& Chou L.M. (Eds.) Proceedings of 3rd ASEAN-Australia Symposium on Living Coastal Resources, 507514. Bangkok: Chulalongkorn University.

Koike, I., Ogawa, H., Nagata, T., Fukuda, R. \& Fukuda, H. (2001). Silicate to Nitrate Ratio of the Upper Sub-Arctic Pacific and the Bering Sea Basin in Summer: Its Implication for Phytoplankton Dynamics. Journal of Oceanography, 57, 253260. 
Levich, A. P. (1996). The role of nitrogen-phosphorus ratio in selecting for dominance of phytoplankton by cyanobacteria or green algae and its application to reservoir management. Journal of Aquatic Ecosystem Health, 5(1), 55-61.

Mackentum, K. M. (1969). The practice of water pollution biology. United States Department of Interior, Federal Water Pollution Control Administration, Division of Technical Support, $411 \mathrm{p}$.

Muchtar, M. (2000). Konsentrasi fosfat di beberapa Perairan Indonesia. In Praseno et. al. (Eds.). Teluk Bayur dan Teluk Bungus: Kajian tentang zat hara serta kaitannya dengan lingkungan dan sumberdaya hayati (pp. 4-13). Proyek Inventarisasi dan Evaluasi Potensi Laut - Pesisir, P2O-LIPI, Jakarta.

Mustofa, A. (2015). Kandungan nitrat dan pospat sebagai faktor tingkat kesuburan perairan pantai. Jurnal Disprotek, 6(1): 13-19.

National Research Council. (2000). Clean coastal waters: Understanding and reducing the effects of nutrient pollution. Washington, DC: The National Academies Press.

Nontji, A. (1984). Biomassa dan Produktivitas Fitoplankton di Perairan Teluk Jakarta serta Kaitannya dengan Faktor-faktor Lingkungan. Tesis. Pascasarjana: IPB Bogor.

Odum, E. P. (1971). Fundamentals of Ecology. W. B. Sounders Company Ltd. Philadelphia.

Peraturan Pemerintah Republik Indonesia Nomor 26 Tahun 2012 Tentang Kawasan Ekonomi Khusus Tanjung Lesung.

Qian, P-Y., Wu, M. C. S. \& Ni, I-H. (2001). Comparison of nutrients release among some maricultured animals. Aquaculture, 200, 305-316.

Rasyid, A. (2010). Distribusi suhu permukaan pada musim peralihan barat-timur terkait dengan fishing ground ikan pelagis kecil di Perairan Spermonde. Torani, 20(1), 1-7.

Redfield, A. C. (1958). The biological control of chemical factors in the environment. Am. Sci, 46, 205-221.
Richardson, C. J., King, R. S., Qian, S. S., Vaithiyanathan, P., Qualls, R. G., Stow, C. A. (2007). Estimating ecological thresholds for phosphorus in the Everglades. Environmental Science and Technology, 41(23), 8084-8091.

Romimohtarto, K. (1985). Kualitas Air dalam Budidaya Laut. Seafarming Workshop Report Bandar Lampung. Lampung: FAO/UNDP.

Rudi, E. (2000). Ekologi dan makanan kerang M. meretrix Linnaeus 1758. Makalah disampaikan dalam Seminar Hasil Penelitian Dosen FMIPA Unsyiah. Banda Aceh, Juni 2000.

Rustam, A., Kepel, T. L., Ati, R. N. A., Salim, H. L., Kusumaningtyas, M.A., Daulat, A., Mangindaan, P., Sudirman, N., Rahayu, Y., Suryono, D., Hutahaean, A. (2014). Peran ekosistem lamun sebagai Blue Carbon dalam mitigasi perubahan iklim: studi kasus Tanjung Lesung, Banten. $J$. Segara, 10(2), 107-117.

Salmin. (2005). Oksigen Terlarut (DO) dan Kebutuhan Oksigen Biologi (BOD) Sebagai Salah Satu Indikator Untuk Menentukan Kualitas Perairan. Oseana, 30(3), 21-26.

Tilman, D., Kilham, S. S. \& Kilham, P. (1982) Phytoplankton community ecology: the role of limiting nutrients. Annu. Rev. Ecol. Syst.,13, 349-372.

Tilman, D., Kiesling, R. L., Sterner, R., Kilham, S. S., \& Johnson, F. A. (1986). Green, bluegreen and diatom algae: taxonomic differences in competitive ability for phosphorus, silicon, and nitrogen. Arch. Hydrobiol, 106, 473-485.

Tsunogai, S. \& Watanabe, Y. (1983). Role of dissolved silicate in the occurrence of a phytoplankton bloom. Journal of the Oceanographical Society of Japan, 39: pp. 231-239.

WHO \& European Commission. (2002). Eutrophication and health. The European Communities, Luxembourg: 28pp.

Yang, X., Wu, X., Hao, H. \& He, Z. (2008). Mechanisms and assessment of water eutrophication. $J$. Zhejiang Univ Sci B, 9(3): 197-209. 